\title{
Lower variability of radionuclide activities in upland dairy products compared to soils and vegetation: Implication for environmental survey
}

\author{
L. Pourcelot ${ }^{a}$, P. Steinmann ${ }^{b}$, P. Froidevaux ${ }^{b, *}$ \\ a Institut de Radioprotection et de Sûreté Nucléaire IRSN, CEA Cadarache Bat 153, 13108 St Paul Lez Durance, France \\ ${ }^{\mathrm{b}}$ Institute of Applied Radiophysics, University of Lausanne, Grand Pré 1, 1007 Lausanne, Switzerland
}

Received 11 May 2006; received in revised form 2 August 2006; accepted 7 August 2006

Available online 26 September 2006

\begin{abstract}
Contamination of the environment by radionuclides is usually estimated using soil and grass sampling. However, radionuclides are often not homogeneously distributed in soils. In the alpine Mercantour region (Western Alps, France) a large heterogeneity in Chernobyl ${ }^{137} \mathrm{Cs}$ deposition has been previously observed. Here we report additional ${ }^{137} \mathrm{Cs}$ results together with new ${ }^{90} \mathrm{Sr}$ and $\mathrm{Pu}$ data for soil, grass, milk, and cheese samples. The results show that radioisotopes from nuclear weapons tests fallout are more homogeneously distributed than Chernobyl ${ }^{137} \mathrm{Cs}$. Further, we observe that the ${ }^{137} \mathrm{Cs}$ and ${ }^{90} \mathrm{Sr}$ contents are less variable in milk samples than in grass or soil samples. This can be attributed to the homogenization effect of cow vagrancy during grazing. Hence milk seems to be a more robust sample than soil or grass to evaluate the extent of contamination on a regional scale. We explore this idea by comparing own unpublished ${ }^{90} \mathrm{Sr}$ results and ${ }^{90} \mathrm{Sr}$ results from the literature to establish the relationship between altitude of grazing and contamination of soil and milk for Western Europe. There is a significant positive correlation between soil contamination and altitude and an even closer correlation between milk ${ }^{90} \mathrm{Sr}$ activity $(A)$ and altitude $(h): A=A_{0}+\mathrm{e}^{k \cdot h}$ where $A_{0}$ is the expected activity of milk sampled at sea level $\left(A_{0}=0.064 \pm 0.014 \mathrm{~Bq} \mathrm{~g}^{-1}\right.$ $\mathrm{Ca})$ and $h$ is the altitude of grazing, $k$ being a constant $\left(k=0.95 \times 10^{-3} \pm 0.11 \times 10^{-3} \mathrm{~m}^{-1} \mathrm{~Bq} \mathrm{~g}^{-1} \mathrm{Ca}\right)$. The fact that there is less scattering

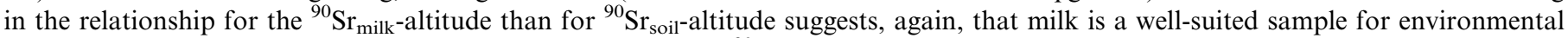
survey. The relationship between the altitude of grazing and the ${ }^{90} \mathrm{Sr}$ content of milk and cheese can also be used to assess the authenticity of dairy products.
\end{abstract}

(c) 2006 Elsevier Ltd. All rights reserved.

Keywords: Soil; Grass; Milk; ${ }^{90} \mathrm{Sr} ;{ }^{137} \mathrm{Cs}$; Transfer model

\section{Introduction}

A consequence of the increased precipitation that occurs on mountainous areas is the higher contamination of soils by global atmospheric radioactive fallout. In alpine ecosystems, differences in altitude, vegetation cover, local topography and soil properties result in large

\footnotetext{
* Corresponding author. Tel.: +4121623 34 80; fax : +4121623 3435

E-mail addresses: laurent.pourcelot@irsn.fr (L. Pourcelot), philipp. steinmann@chuv.ch (P. Steinmann), pascal.froidevaux@chuv.ch (P. Froidevaux).
}

heterogeneity of the field distribution of contaminants (Lettner et al., 1999; Albers et al., 2000; Gastberger et al., 2000; Ulsh et al., 2000; Pourcelot et al., 2003). The soils of these regions are characterized by a large variability in fission products (Cs isotopes, ${ }^{90} \mathrm{Sr}$ ) and actinides $(\mathrm{Pu}$ isotopes, $\mathrm{Am})$ inventories due to the accumulation of fallout from different episodes: Nuclear Weapons Tests (hereinafter NWT), SNAP Satellite burn up, Chernobyl fallout.

In the long term, the transfer of trace contaminants from the soil compartment to human food chains is controlled by their uptake by plants (Gastberger et al., 2000; Ehlken and 
Kirchner, 2002; Schimmack et al., 2003). Foliar absorption and surface adhesion of re-suspended contamination on leaves and stems should also be taken into account (Beresford et al., 2002; Malek et al., 2002). Moreover, it is well known that radiocesium has a reduced availability for plant root uptake when strongly sorbed to clay minerals. These few examples already illustrate the complexity of the process.

Radionuclide transfer from soil-to-plant has often been characterized by the concentration ratio (CR), assuming a linear relationship between soil activity and plant activity. While the linear relationship is probably justified under similar environmental conditions it has been shown to be the exception rather than the rule in statistical treatment of published databases (Albers et al., 1998; Albers et al., 2000; Ehlken and Kirchner, 2002; Schimmack et al., 2003). Thus, recent models to predict soil-to-plant transfer of radionuclides more and more incorporate soil chemical and physical properties, root zone radionuclide availability and soil/soil-solution interactions (Ehlken and Kirchner, 2002). Moreover, Bundt et al. (2000) showed a heterogeneous distribution of ${ }^{137} \mathrm{Cs}$ and plutonium in the root zone of a forest soil due to the presence of preferential flow paths. Due to the more intense rooting along the preferential flow paths this phenomenon must be incorporated into soil-to-plant transfer models (Bundt et al., 2000). Thus, site-specific parameterization tends to replace generic parameterization in models. The introduction of complexity into the modelling demands more complete field characterization. Amongst the parameters needed for complete radiological assessment, field heterogeneity is poorly documented.

A previous field study on the meadows of the Mercantour mountains (Western Alps, France) has shown significant variability in Chernobyl caesium in soil, while the repartition of nuclear weapons tests fallout is assumed to be more homogeneous. One important reason for this heterogeneity is fallout enrichment related to snow accumulation (Pourcelot et al., 2003). The high variability at small $(10 \mathrm{~m})$ scale would require a large number of soil samples to accurately estimate large $(\mathrm{km})$ scale deposition. It, therefore, may be questioned whether soil (or grass) samples are appropriate indicators for average contamination over a larger area.

In this paper a new approach to the environmental survey of uplands areas contaminated by atmospheric deposition is proposed. Based on the here presented results of the heterogeneous Mercantour site we suggest that milk (and cheese) samples are a more robust indicator of radioisotope contamination than are soil or grass samples. This is due to the fact that a cow covers large surface during grazing and by that the contamination of its milk is averaged out. Here, ${ }^{137} \mathrm{Cs}$ and ${ }^{90} \mathrm{Sr}$ in milk and ${ }^{90} \mathrm{Sr}$ in cheese will be compared to the corresponding soil and grass samples and will be used to characterize the level of deposition in the Mercantour area. We then further test the 'robustness' of milk samples using a larger data set including own unpublished ${ }^{90} \mathrm{Sr}$ data and literature data from Western Europe.

\section{Experimental methods}

\subsection{Investigated area}

The investigated area and its soils have already been described in Pourcelot et al. (2003). It is located in the Mercantour Massif (southern part of the Western Alps in France), around the pass of the Col de la Lombarde (altitude $2350 \mathrm{~m}$ above sea level) approximately $80 \mathrm{~km}$ north of Nice (France). In this area, meadow, pine forests, and scree areas each represent one third of the catchment area $\left(27 \mathrm{~km}^{2}\right)$.

The vegetative period begins after snow thaw, generally at the beginning of May, and lasts till October. During this period, cowherds graze the grass extensively. Two farms St. Anna (N) and Isola2000 (S) - manufacture cheese from their own farm-produced milk. The St. Anna (N) farm lies ca. $1 \mathrm{~km}$ to the north of the pass at an altitude of $2200 \mathrm{~m}$, while the Isola2000 (S) farm lies ca. $1 \mathrm{~km}$ to the south of the pass at an altitude of $2000 \mathrm{~m}$. Although the cows probably graze more often in the vicinity of "their" farm, the cows of the two farms were not strictly kept at either side of the pass. At the Isola2000 (S) farm, in addition to meadow grass, cows are fed with corn flour, whereas cows from the St. Anna (N) farm do not get any additional food.

\subsection{Sampling strategy}

Soil and grass sampling are focused on a small grazing parcel (surface $=2125 \mathrm{~m}^{2}$ ) located at the south of the "Col de la Lombarde" pass. Pourcelot et al. (2003) demonstrated a high variability of radiocesium deposition within this study plot. Their soil contamination mapping (using a portable NaI detector) identified an 'enriched area' that covers only about $6 \%$ of the study plot but contains half of the Cs inventory. The surface activity of the enriched area may exceed $100000 \mathrm{~Bq} \mathrm{~m}^{-2}$. The remaining larger part of the study plot exhibits activities of around $10000 \mathrm{~Bq} \mathrm{~m}^{-2}$. It is hereinafter referred to as 'background area'.

Before litter and soil sampling, grass covering one square meter surface was cut on each site. Then litter and soil samples were collected from a $400 \mathrm{~cm}^{2}$ square surface area. Soil samples were cleaned from roots and pebbles and dried at $105^{\circ} \mathrm{C}$ before sieving. Litter samples were sieved to separate coarse $(>2 \mathrm{~mm})$ and fine litter fractions $(<2 \mathrm{~mm})$. Soil samples were also dry-sieved to separate coarse $(>2 \mathrm{~mm})$, medium $(2-0.2 \mathrm{~mm})$ and fine soil fractions $(0.2-0.05 \mathrm{~mm})$. Soil and grass samples were dried and crushed prior to analyses.

In addition to the previous samples, for the present study each summer between 1999 and 2003, 51 milk and $3 \mathrm{~kg}$ cheese were collected in the two farms. At the same 
time, the fresh pasture grass covering a surface area of $1 \mathrm{~m}^{2}$ was cut.

\subsection{Radioisotope analysis}

Gamma spectrometry analyses were performed on volumes of $17 \mathrm{ml}$ for the dried soil and grass samples and $60 \mathrm{ml}$ for milk and cheese ashes, using high-purity germanium detectors (Ortec GMX) and multichannel analysers (Ortec 752, Silena $7411 \mathrm{~S}$ ), to determine the ${ }^{137} \mathrm{Cs}$ and ${ }^{40} \mathrm{~K}$ activities (Bouisset and Calmet, 1997).

The samples were ashed at $550{ }^{\circ} \mathrm{C}$ for $24 \mathrm{~h}$ prior to microwave leaching ( $5 \mathrm{~g}$ of soil, milk, grass or cheese ash) in $50 \mathrm{ml} \mathrm{HNO}_{3} 8 \mathrm{M}$ (Milestone ultraclave, $170{ }^{\circ} \mathrm{C}$, 140 bar, $30 \mathrm{~min}$ ). ${ }^{90} \mathrm{Sr}$ was determined in the soil, grass, milk and cheese samples using the method described in Froidevaux et al. (2002). Calcium was determined by atomic absorption (Perkin-Elmer 4100). Following Currie (1995) the detection limits for ${ }^{90} \mathrm{Sr}$ are $0.5 \mathrm{~Bq} \mathrm{~kg}^{-1}$ for soil, $0.1 \mathrm{~Bq} \mathrm{~kg}^{-1}$ for grass and $5 \mathrm{mBq} \mathrm{g}^{-1} \mathrm{Ca}$ for dairy products.

For plutonium analysis, the soil ashes $(5 \mathrm{~g})$ were spiked with ${ }^{242} \mathrm{Pu}$ prior to microwave leaching. Plutonium was then co-precipitated from the acidic solution with calcium oxalate at $\mathrm{pH}$ 1.5. The oxalates were wet ashed in concentrated nitric acid $(20 \mathrm{ml})$ in the microwave apparatus at $190{ }^{\circ} \mathrm{C}$ and 160 bars for $35 \mathrm{~min}$. After dilution to about $8 \mathrm{M}$ in nitric acid the solutions were pumped on an anionic exchanger (AG $1 \times 8,10 \mathrm{ml}$ ). The plutonium was eluted from the exchanger with a hydroxylamine solution $(50 \mathrm{ml})$ and purified from thorium and uranium on a smaller column (AG $1 \times 8,2 \mathrm{ml}$ ) by rinsing the column with concentrated hydrochloric acid $(40 \mathrm{ml})$ and $\mathrm{HNO}_{3} 4 \mathrm{M}(30 \mathrm{ml})$. The plutonium was electrodeposited on a stainless steel disc from a sulphate buffer at $1.2 \mathrm{~A}$ during $75 \mathrm{~min}$. Alpha spectra were recorded on a Canberra Alpha Analyst spectrometer with PIPS detectors. The detection limit is $1.0 \mathrm{mBq} \mathrm{kg}{ }^{-1}$ dry weight.

The results are expressed in $\mathrm{Bq} \mathrm{kg}^{-1}$ dry weight for soil, grass and cheese and in $\mathrm{Bq} 1^{-1}$ for milk. For the dairy prod- ucts the ${ }^{90} \mathrm{Sr}$ activities are also normalized to the calcium content of the sample.

The ${ }^{90} \mathrm{Sr}$ deposition of the additional Swiss samples cited as 'unpublished' in Table 3 were sampled between 1992 and 2003 and analysed in the same laboratory as the Mercantour samples (GSE-laboratory of IRA). The samples were obtained by core sampling to a depth of at least $20 \mathrm{~cm}$ and analysed using the method described in Geering et al. (1990). Soils from NE France in the Vosges (Aubure) and Jura (Boissia, Les Rousses and Bellefontaine) mountains were sampled to a depth exceeding $20 \mathrm{~cm}$ between 2001 and $2005 .{ }^{90} \mathrm{Sr}$ analysis of these soils were carried out by successive precipitation of hydroxide, oxalate and, after an ingrowth period of 15 days, $\mathrm{Y}(\mathrm{OH})_{3}$ scavenging to isolate ${ }^{90} \mathrm{Y}$. The activity of ${ }^{90} \mathrm{Y}$ is subsequently determined in a proportional counter. ${ }^{90} \mathrm{Sr}$ activities were corrected to the 15 June 2004.

\section{Results and discussion}

\subsection{Soils}

The soil data from the Mercantour region are summarized in Table 1. As discussed by Pourcelot et al. (2003) there is a large variation in ${ }^{137} \mathrm{Cs}$ activity, which is mainly of Chernobyl origin. The ${ }^{137} \mathrm{Cs}$ activity increases along the gradient of increasing field activity PNM $10<$ PNM $12<$ PNM14. It is higher in the litter than in the underlying soil (up to 10 times) and it is higher in the finest fraction (up to ca. 2 times) for both, the litter samples and the soil samples.

The data of nuclear weapons tests fallout of Cs and ${ }^{241} \mathrm{Am}$ reported by Pourcelot et al. (2003) as well as the $\mathrm{Pu}$ and ${ }^{90} \mathrm{Sr}$ data reported here show that these older contaminations are less heterogeneously distributed. For $\mathrm{Pu}$ a gradient from background area PNM10 to enriched areas PNM12 and PNM14 is still apparent, but for ${ }^{90} \mathrm{Sr}$ an important enrichment is not observed. Moreover, the results of the different granulometric fractions measured on PNM12 suggest that

Table 1

\begin{tabular}{|c|c|c|c|c|c|c|c|c|c|c|c|}
\hline No. & $\begin{array}{l}\text { Depth } \\
(\mathrm{cm})\end{array}$ & Type & $\begin{array}{l}\text { Grain size } \\
\text { class }(\mathrm{mm})\end{array}$ & $\begin{array}{l}\mathrm{wt}^{0} \% \\
\text { of total }\end{array}$ & ${ }^{137} \mathrm{Cs}$ & ${ }^{134} \mathrm{Cs}$ & ${ }^{90} \mathrm{Sr}$ & ${ }^{90} \mathrm{Sr}(\mathrm{Bq} / \mathrm{g} \mathrm{Ca})$ & ${ }^{239+240} \mathrm{Pu}$ & ${ }^{238} \mathrm{Pu}$ & ${ }^{238} \mathrm{Pu} /{ }^{239+240} \mathrm{Pu}$ \\
\hline 9 & & Grass & & & $39 \pm 3$ & $<$ d.l. & $156 \pm 2$ & $23.8 \pm 0.6$ & - & - & \\
\hline $10-2$ & $0-2$ & Litter & $<2$ & 72 & $1180 \pm 80$ & $4.6 \pm 0.8$ & $160 \pm 7$ & $18 \pm 1$ & $11.5 \pm 0.4$ & $0.32 \pm 0.02$ & $0.028 \pm 0.002$ \\
\hline $10-4$ & $2-5$ & Soil & $2-0.2$ & 52 & $193 \pm 13$ & $0.6 \pm 0.3$ & $86 \pm 5$ & $3.9 \pm 0.5$ & $3.5 \pm 0.1$ & $0.08 \pm 0.01$ & $0.023 \pm 0.003$ \\
\hline 11 & & Grass & & & $1480 \pm 100$ & $2.6 \pm 0.3$ & $43 \pm 5$ & $7.9 \pm 0.4$ & - & - & - \\
\hline $12-1$ & $0-2$ & Litter & $>2$ & 41 & $570 \pm 400$ & $40 \pm 3.1$ & $79 \pm 1$ & $20.3 \pm 0.3$ & $15.1 \pm 0.5$ & $0.35 \pm 0.02$ & $0.023 \pm 0.002$ \\
\hline $12-2$ & $0-2$ & Litter & $<2$ & 59 & $13000 \pm 900$ & $88 \pm 6.0$ & $78 \pm 4$ & $18.1 \pm 0.6$ & $12.1 \pm 0.5$ & $0.3 \pm 0.04$ & $0.025 \pm 0.003$ \\
\hline $12-3$ & $2-5$ & Soil & $>2$ & 40 & $1270 \pm 90$ & $6.1 \pm 1.1$ & $114 \pm 4$ & $24.3 \pm 0.8$ & $9.2 \pm 0.3$ & $0.19 \pm 0.03$ & $0.021 \pm 0.003$ \\
\hline $12-4$ & $2-5$ & Soil & $2-0.2$ & 54 & $1660 \pm 110$ & $9.2 \pm 0.9$ & $106 \pm 3$ & $22.1 \pm 0.6$ & $13.4 \pm 0.27$ & $0.27 \pm 0.02$ & $0.020 \pm 0.002$ \\
\hline $12-5$ & $2-5$ & Soil & $0.2-0.05$ & 6 & $1830 \pm 120$ & $10 \pm 1.4$ & $75 \pm 2$ & $25 \pm 0.5$ & $8.6 \pm 0.3$ & $0.18 \pm 0.02$ & $0.021 \pm 0.002$ \\
\hline 13 & & Grass & & & $3130 \pm 200$ & $6.6 \pm 0.8$ & $137 \pm 2$ & $20.9 \pm 0.4$ & - & - & - \\
\hline $14-2$ & $0-2$ & Litter & $<2$ & 63 & $44000 \pm 2800$ & $332 \pm 21$ & $304 \pm 12$ & $44 \pm 2$ & $23.1 \pm 0.9$ & $0.72 \pm 0.05$ & $0.031 \pm 0.002$ \\
\hline $14-5$ & $2-5$ & Soil & $0.2-0.05$ & 5 & $17300 \pm 1100$ & $120 \pm 10$ & $84 \pm 4$ & $13 \pm 1$ & $34.7 \pm 1.4$ & $0.80 \pm 0.05$ & $0.023 \pm 0.002$ \\
\hline
\end{tabular}

Sampling date was 15/06/99. 
Table 2

${ }^{239+340} \mathrm{Pu},{ }^{90} \mathrm{Sr}$ and ${ }^{137} \mathrm{Cs}$ inventories in soil profiles of the study area (in $\mathrm{Bq} \mathrm{m}^{-2}$ )

\begin{tabular}{lclcc}
\hline Soil profile & ${ }^{239+240} \mathrm{Pu}$ & ${ }^{90} \mathrm{Sr}$ & ${ }^{137} \mathrm{Cs}_{\text {Chernobyl }}$ & ${ }^{137} \mathrm{Cs}_{\text {NWT }}$ \\
\hline PNM10 & $86 \pm 5$ & $1700 \pm 114$ & $3000 \pm 720$ & $4000 \pm 850$ \\
PNM12 & $145 \pm 7$ & $1100 \pm 52$ & $48000 \pm 9000$ & $17000 \pm 10000$ \\
PNM14 & $397 \pm 17$ & $2465 \pm 142$ & $240000 \pm 37000$ & $53000 \pm 41000$ \\
\hline
\end{tabular}

$\mathrm{Pu}$ and $\mathrm{Sr}$ are rather homogeneously distributed over the different size fractions (Table 1).

The ${ }^{137} \mathrm{Cs}$, plutonium and ${ }^{90} \mathrm{Sr}$ inventories highlight the differences between the studied radionuclides (Table 2). Radiostrontium inventory varies by a factor of approximately two. The Plutonium inventory is almost five times higher in the enriched site than in the background site. For the NWT-Cs this difference is one order of magnitude. The largest differences (two orders of magnitudes) are observed for Chernobyl-Cs, which is a consequence of local redistribution of radionuclides induced by snowdrifts and runoff effects (Pourcelot et al., 2003). Although ${ }^{90} \mathrm{Sr}$ has the same source as plutonium and ${ }^{137} \mathrm{Cs}_{\mathrm{NWT}}$ its soil inventory is less variable. This can be attributed to the higher mobility of $\mathrm{Sr}$ in the studied environment. The transfer from the soil to the grass of alpine pastures, e.g., is one to two orders of magnitude higher for ${ }^{90} \mathrm{Sr}$ than for ${ }^{137} \mathrm{Cs}$ (Gastberger et al., 2000). Thus, the higher mobility may account for the field redistribution of atmospheric fallout in the years following ${ }^{90} \mathrm{Sr}$ deposition. A further conse- quence of the higher mobility of ${ }^{90} \mathrm{Sr}$ with respect to ${ }^{137} \mathrm{Cs}$ and plutonium is a larger vertical ${ }^{90} \mathrm{Sr}$ migration in the soil (Baeza et al., 1999; Bunzl et al., 2000; Gastberger et al., 2000). This may lead to a loss of ${ }^{90} \mathrm{Sr}$ from the soil profile, especially in conjunction with the low thickness of the Mercantour soil. However, the highest of the here reported inventories is close to a value measured on a $30 \mathrm{~cm}$ deep peat profile from the same region (Pourcelot, unpublished results).

With respect to large scale distribution of atmospheric fallout previous studies reported a correlation between the mean annual rainfall and soil ${ }^{137} \mathrm{Cs}$ or $\mathrm{Pu}$ inventories (Mitchell et al., 1990; Hölgye and Filgas, 1995; Wright et al., 1999). Touazi et al. (2004) showed that parameters such as location of pluviometer and especially altitude explain $67 \%$ of the variance when mapping mean precipitation amount. In Western Europe increasing precipitation is correlated with altitude when clouds are forced to pass over mountain chains such as the Alps, the Pyrenees, or the Jura Mountains. In addition to rain, dry deposition and snow deposition may also be increasing with altitude. In some cases dry deposition could explain the fact that a higher soil inventory was found than expected from the precipitation rate. An example is the site of Davos (Table 3) with a high inventory of $2140 \mathrm{~Bq} \mathrm{~m}^{-2}$ and a comparatively low precipitation of $1055 \mathrm{~mm}$. Perhaps the interception of dry air mass by the mountains might be responsible of such a high deposition. A positive correlation between altitude and soil

Table 3

${ }^{90} \mathrm{Sr}$ inventory in some Western European soils (decay corrected to $15 / 06 / 2004$ )

\begin{tabular}{|c|c|c|c|c|c|c|}
\hline Location & Country & $\begin{array}{l}\text { Elevation } \\
(\mathrm{m})\end{array}$ & $\begin{array}{l}\text { Soil thickness } \\
(\mathrm{cm})\end{array}$ & $\begin{array}{l}{ }^{90} \mathrm{Sr} \\
\left(\mathrm{Bq} \mathrm{m}^{-2}\right)\end{array}$ & $\begin{array}{l}\text { Mean annual } \\
\text { precipitation }(\mathrm{mm})^{\mathrm{c}}\end{array}$ & References \\
\hline Mollendruz & $\mathrm{CH}$ & 1200 & 30 & 1740 & 1620 & This work \\
\hline Marchairuz & $\mathrm{CH}$ & 1390 & 30 & 2637 & 1930 & This work \\
\hline St-Cergue & $\mathrm{CH}$ & 1040 & 40 & 1412 & 1880 & J.-J. Geering (unpublished) \\
\hline Plateau Suisse & $\mathrm{CH}$ & 400 & 30 & 622 & 900 & J.-J. Geering (unpublished) \\
\hline Arenenberg & $\mathrm{CH}$ & 450 & 20 & 374 & 900 & J.-J. Geering (unpublished) \\
\hline Gordola & $\mathrm{CH}$ & 500 & 35 & 456 & 1910 & J.-J. Geering (unpublished) \\
\hline Isola2000 & $\mathrm{F}$ & 2350 & 5 & 2465 & & This work \\
\hline Vésinet & $\mathrm{F}$ & 30 & 20 & 306 & 800 & IRSN database \\
\hline $\begin{array}{l}\text { Aubure } \\
\quad \text { (Vosges) }\end{array}$ & $\mathrm{F}$ & 950 & 40 & 1653 & 1330 & $\begin{array}{l}\text { Solovitch-Vella et al. (in } \\
\text { prepration) }\end{array}$ \\
\hline Boissia & $\mathrm{F}$ & 500 & 30 & 1411 & & This work \\
\hline Urbino & I & 450 & 45 & 1482 & 870 & Jia et al. (1999) \\
\hline Nassefeld & A & 1600 & 30 & 1344 & & Gastberger et al. (2000) \\
\hline Postalm & A & 1300 & 30 & 1956 & & Gastberger et al. (2000) \\
\hline Ursprung & A & 500 & 30 & 1442 & 1150 & Gastberger et al. (2000) \\
\hline Zinkenbach & A & 500 & 30 & 1632 & 1150 & Gastberger et al. (2000) \\
\hline Berchtesgaden & $\mathrm{D}$ & 1500 & 50 & 9115 & & Schimmack et al. (2003) \\
\hline
\end{tabular}

${ }^{a}$ This inventory has been taken into account even if profile depth is only $10 \mathrm{~cm}$ because more than $90 \%$ of the inventory is in the first $4 \mathrm{~cm}$.

b Forest soil.

${ }^{\text {c }}$ For $\mathrm{CH}$ and $F$ samples the precipitation is average of monthly precipitation from 1960 to 1970 (Meteosuisse and Meteo France). 
inventory has never been established before for ${ }^{90} \mathrm{Sr}$. We compiled unpublished measurements of ${ }^{90} \mathrm{Sr}$ in some soils in Switzerland and France sampled at different altitudes and soil data from published studies carried out in Western Europe (Baeza et al., 1999; Jia et al., 1999; Gastberger et al., 2000; Schimmack et al., 2003; Hölgye et al., 2004). Only recent data were taken into account and attention was paid to the soil thickness (larger than $20 \mathrm{~cm}$ ) to reduce ${ }^{90} \mathrm{Sr}$ migration effect on soil inventory (Table 3 ). When several inventories are reported for one location we reported the highest one in Table 3 and Fig. 1. The precipitation rates are not always known for these sampling sites and thus the correlation between mean rain amount and soil
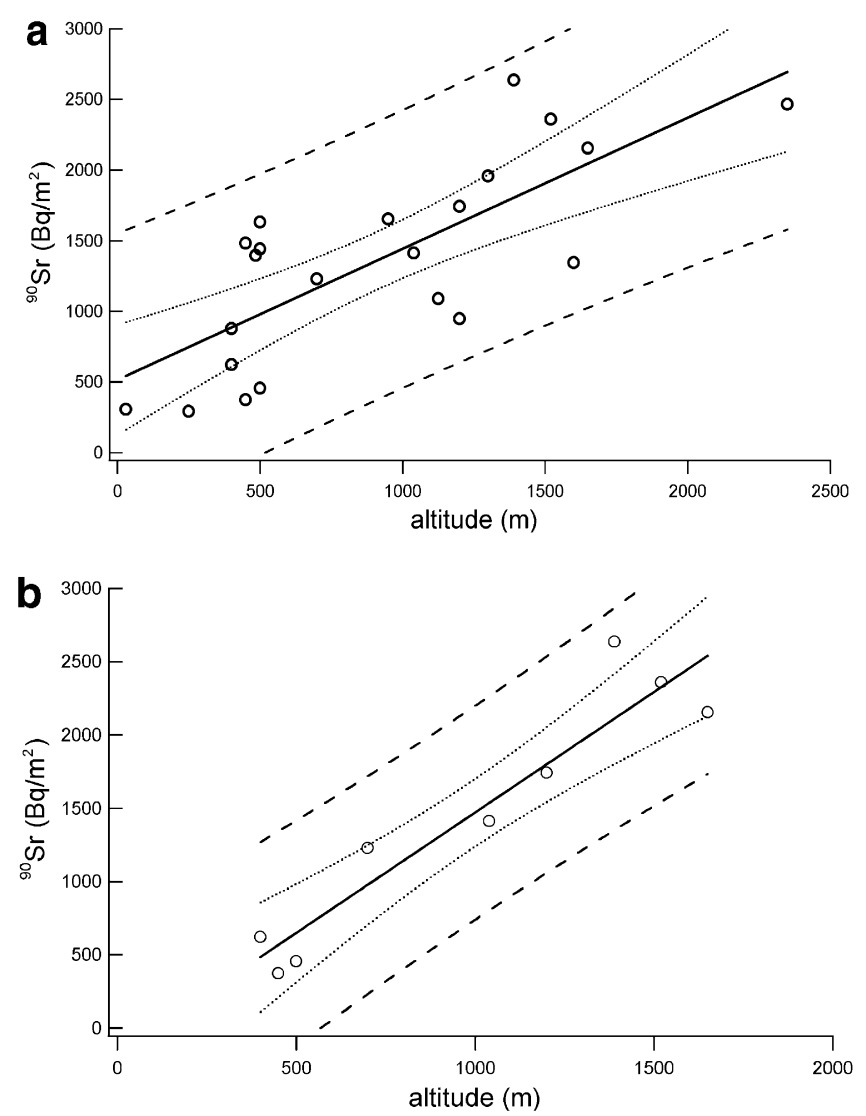

Fig. $1 .{ }^{90} \mathrm{Sr}$ soil inventory in some western European soils as a function of the altitude of sampling (decay corrected to 15/06/2004). Data from: a) Table 3, without Berchtesgaden; b) Switzerland only. inventory cannot be established. However, the data clearly evidence a correlation between altitude and soil inventory (Fig. 1a and b).

A good portion of the scatter in Fig. 1a is likely due to the large heterogeneity of soil Sr-inventories of field study sites (on a 10's of $\mathrm{m}$ scale), which are due to varying degree of deposition and of Sr loss from the soil profile. The relationship between altitude and ${ }^{90} \mathrm{Sr}$ deposition shown in Fig. $1 \mathrm{~b}$ seems to be reasonably constraint for the samples from Switzerland $(\mathrm{CH}$, Table 3). The samples from France (F) and Italy (I) show a similar trend, however, the Mercantour soil $(2350 \mathrm{~m})$ exhibits lower activity $\left(2465 \mathrm{~Bq} \mathrm{~m}^{-2}\right)$ compared to the reported trend. Possibly this is due to the loss of ${ }^{90} \mathrm{Sr}$ in low thickness Mecantour profiles. The samples from Austria (A) and Germany (D), however, show no clear trend with altitude and comparatively high inventories.

We might combine the relationship between the inventory and the altitude as depicted in Fig. 1a with the hypsographic curve of a region in order to estimate the deposition at a larger scale. Table 4 shows the result of this exercise for Switzerland. The linear interpolation of the data points from Switzerland (Fig. 1b) gives: $A=$ $-173( \pm 547)+1.64( \pm 0.5)$ altitude; where $\mathrm{A}$ is the soil inventory (in $\mathrm{Bq} \mathrm{m}^{-2}$ ). With that we obtain a total ${ }^{90} \mathrm{Sr}$ inventory of $75 \mathrm{TBq}$. As shown in Table 4 an important percentage of Switzerland's surface lies above the "calibration range" of the ${ }^{90} \mathrm{Sr}$-altitude function. Because the deposition is high at high altitudes this adds uncertainty to our estimate. For our estimate we assumed, somewhat arbitrarily, that a deposition of $3000 \mathrm{~Bq} \mathrm{~m}^{-2}$ is not exceeded even at high altitude. UNSCEAR (1977) gives a soil inventory of $3.15 \times 10^{9} \mathrm{~Bq} \mathrm{~km}{ }^{-2}$ for $40^{\circ}-50^{\circ} \mathrm{N}$ (latitude of Switzerland, $46^{\circ} \mathrm{N}$ ) at the reference date of 1977. Transposed to Switzerland's total surface and corrected to the 15.06.2004 reference date, the inventory becomes $67 \mathrm{TBq}$. Thus our estimate based on the hypsographic model seems to produce realistic values for an alpine region.

\subsection{Grass contamination and soil-to-vegetation-transfer}

The results of grass contamination by ${ }^{137} \mathrm{Cs}$ and ${ }^{90} \mathrm{Sr}$ are displayed in Table 5. The variability of ${ }^{137} \mathrm{Cs}$ grass

Table 4

Estimation of ${ }^{90} \mathrm{Sr}$ deposition in Switzerland (decay corrected to 15/06/2004) based on the altitude-deposition relationship from Fig. $1 \mathrm{~b}$ and a hypsometric model

\begin{tabular}{lllcrc}
\hline Altitude range $^{\text {a }}$ (m a.s.l.) & Mean altitude (m a.s.1.) & \% of surface & Surface $\left(\mathrm{km}^{2}\right)$ & Mean deposition $\left(\mathrm{Bq} \mathrm{m}^{-2}\right)$ & Total dep. (TBq) \\
\hline $300-500$ & 400 & 20 & 8400 & 480 & 4.0 \\
$500-750$ & 625 & 17 & 7140 & 850 & 6.0 \\
$750-1100$ & 925 & 15 & 6300 & 1340 & 8.4 \\
$1100-2500$ & 1800 & 38 & 15960 & 2750 & 44.0 \\
$>2500$ & ca. 2750 & 10 & 4200 & 3000 & 12.6 \\
Estimated total deposition (TBq)
\end{tabular}

${ }^{\mathrm{a}}$ The chosen ranges correspond to straight segments of the hypsographic curve (after Weingartner and Pearson, 2001). 
Table 5

${ }^{90} \mathrm{Sr}$ and ${ }^{137} \mathrm{Cs}$ activities measured in grass, cheese and milk samples

\begin{tabular}{|c|c|c|c|c|c|c|c|}
\hline \# (Year) & Nature & Sampling site & $\begin{array}{l}\text { Ash content } \\
\text { in grass }(\%)\end{array}$ & $\begin{array}{l}{ }^{40} \mathrm{~K} \\
\left(\mathrm{~Bq} \mathrm{~kg}^{-1} \text { d.m. }{ }^{\mathrm{a}}\right)\end{array}$ & $\begin{array}{l}{ }^{90} \mathrm{Sr} \\
\left(\mathrm{Bq} \mathrm{kg}^{-1} \text { d.m. }{ }^{\mathrm{a}}\right)\end{array}$ & $\begin{array}{l}{ }^{90} \mathrm{Sr} \\
\left(\mathrm{Bq} \mathrm{g}^{-1} \mathrm{Ca}\right)\end{array}$ & $\begin{array}{l}\left.{ }^{137} \mathrm{Cs}^{-1}{ }^{\mathrm{a}}\right) \\
\left(\mathrm{Bq} \mathrm{kg}^{-1} \text { d.m. }\right.\end{array}$ \\
\hline $9(99)$ & Grass & Background (S) & 4.1 & $227 \pm 67$ & $156 \pm 2$ & $23.8 \pm 0.6$ & $39 \pm 3$ \\
\hline $11(99)$ & Grass & Enriched area (S) & 5.5 & $450 \pm 70$ & $43 \pm 5$ & $7.9 \pm 0.4$ & $1480 \pm 100$ \\
\hline $5(01)$ & Grass & Background (S) & 5.4 & $290 \pm 40$ & $79 \pm 3$ & $10.2 \pm 0.3$ & $264 \pm 19$ \\
\hline $6(02)$ & Grass & Background (S) & 12.4 & $181 \pm 33$ & $103 \pm 2$ & $9.5 \pm 0.2$ & $1222 \pm 10$ \\
\hline $7(02)$ & Grass & Enriched area $(\mathrm{S})$ & 19.7 & $188 \pm 81$ & $149 \pm 3$ & $12 \pm 0.2$ & $17747 \pm 161$ \\
\hline $24(02)$ & Grass & Peat $(\mathrm{N})$ & 6.8 & $323 \pm 21$ & $51 \pm 1$ & $5.7 \pm 0.1$ & $1.7 \pm 0.4$ \\
\hline $4(03)$ & Grass & Peat $(\mathrm{N})$ & 6.6 & $281 \pm 32$ & $45 \pm 2$ & $7.9 \pm 0.3$ & $1.6 \pm 1.2$ \\
\hline $5(03)$ & Grass & Background (S) & 3.7 & $230 \pm 25$ & $26 \pm 2$ & $5.1 \pm 0.3$ & $4.4 \pm 1.1$ \\
\hline $44(99)$ & Cheese & St. Anna (N) & & $73 \pm 10$ & $8.4 \pm 1$ & $0.58 \pm 0.06$ & $2.0 \pm 0.2$ \\
\hline $45(99)$ & Cheese & Isola2000 (S) & & $53 \pm 7$ & $6.1 \pm 0.1$ & $0.40 \pm 0.01$ & $5.1 \pm 0.3$ \\
\hline $27(00)$ & Cheese & Isola2000 (S) & & $52 \pm 7$ & $0.67 \pm 0.15$ & $0.05 \pm 0.01$ & $4.4 \pm 0.4$ \\
\hline $1(03)$ & Cheese & Isola2000 (S) & & $58 \pm 4$ & $0.61 \pm 0.05$ & $0.048 \pm 0.004$ & $0.1 \pm 0.06$ \\
\hline $2(03)$ & Cheese & St. Anna (N) & & $80 \pm 5$ & $7.2 \pm 0.2$ & $0.49 \pm 0.01$ & $4.2 \pm 0.3$ \\
\hline $43(99)$ & Milk & St. Anna (N) & & $48 \pm 6$ & $0.65 \pm 0.02$ & $0.59 \pm 0.02$ & $6.2 \pm 0.4$ \\
\hline $42(99)$ & Milk & St. Anna (N) & & $39 \pm 5$ & $0.63 \pm 0.02$ & $0.66 \pm 0.02$ & $5.5 \pm 0.4$ \\
\hline $24(00)$ & Milk & St. Anna (N) & & $48 \pm 7$ & $0.54 \pm 0.02$ & $0.46 \pm 0.02$ & $1.4 \pm 0.1$ \\
\hline $26(00)$ & Milk & Isola2000 (S) & & $51 \pm 7$ & $0.29 \pm 0.01$ & $0.21 \pm 0.01$ & $1.8 \pm 0.1$ \\
\hline $18(02)$ & Milk & Isola2000 (S) & & $53 \pm 3$ & $0.37 \pm 0.01$ & $0.30 \pm 0.01$ & $1.3 \pm 0.1$ \\
\hline $25(02)$ & Milk & St. Anna (N) & & $53 \pm 3$ & $0.77 \pm 0.01$ & $0.62 \pm 0.01$ & $4.8 \pm 0.3$ \\
\hline $26(02)$ & Milk & Isola2000 (S) & & $51 \pm 7$ & $0.58 \pm 0.02$ & $0.45 \pm 0.02$ & $4.0 \pm 0.2$ \\
\hline $3(03)$ & Milk & St. Anna (N) & & $58 \pm 3$ & $0.59 \pm 0.01$ & $0.41 \pm 0.007$ & $4.1 \pm 0.3$ \\
\hline
\end{tabular}

(\# = identification number). Samples 9, 11, and 13 correspond to the soil profiles 10, 12, and 14, respectively.

${ }^{\text {a }}$ Milk activity is expressed in $\mathrm{Bq} \mathrm{l}^{-1}$.

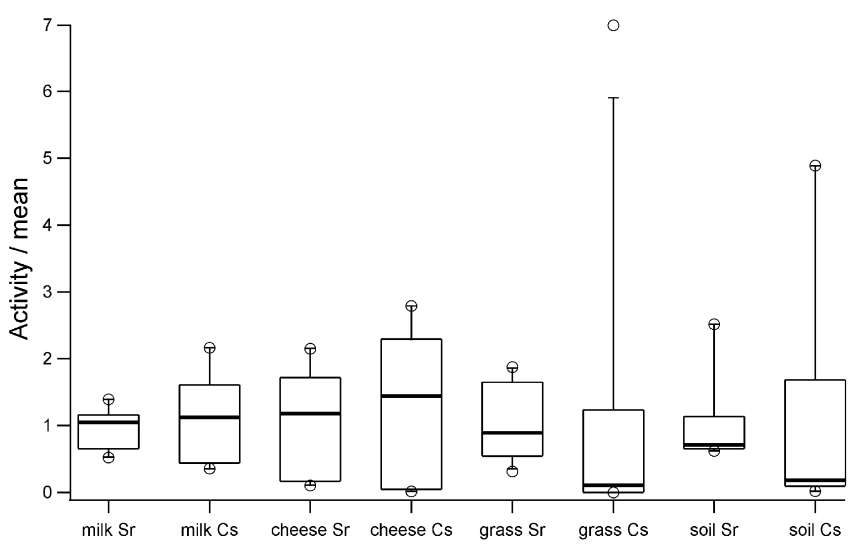

Fig. 2. Boxplot of the activities of ${ }^{90} \mathrm{Sr}$ and ${ }^{137} \mathrm{Cs}$ normalized to the mean of each sets of samples. Top and bottom whiskers are at 90 and 10 percentiles. Box top and bottom are at 75 and 25 percentiles. Bold line represents the median of the values.

contamination is large (see boxplot in Fig. 2). Heterogeneity still exists for ${ }^{90} \mathrm{Sr}$ activities, but the ${ }^{90} \mathrm{Sr}$ content of grass is more homogeneous than the ${ }^{137} \mathrm{Cs}$ content (percentile 90 at 2.5 times the mean against six times the mean for ${ }^{137} \mathrm{Cs}$ in grass, Fig. 2). According to several papers, the grass variability in a single site is usually one order of mag- nitude for ${ }^{90} \mathrm{Sr}$ and two orders of magnitude for ${ }^{137} \mathrm{Cs}$ (Albers et al., 2000; Bunzl et al., 2000; Gastberger et al., 2000; Schimmack et al., 2003).

For the present study the large variability of radiocesium contamination of the grass partly reflects the high soil variability. However, the fact that Cs in the grass is even more variable than in the soil cannot be explained by a simple linear root uptake model. A possible explanation is the adherence of soil particles to vegetation, which may increase the grass activity by a factor of two (Beresford and Howard, 1991). Such a contamination pattern results from the low plant cover, the trampling by the cattle and raindrop splash effect (Albers et al., 2000). Ash content can be used to trace such contaminations (Malek et al., 2002). In the present study, the ash content in the grass samples is very variable $(4.1-30 \%)$ but no clear correlation exists between ash content and Cs activities.

In soil-plant systems the behaviour of alkaline and alkaline-earth trace elements (e.g. Cs and $\mathrm{Sr}$ ) is dominated by competitive interaction with the corresponding major ions (Albers et al., 2000; Ehlken and Kirchner, 2002; Yoshida et al., 2004). Thus, for the $\mathrm{Sr}-\mathrm{Ca}$ pair we may write

$\frac{\mathrm{Sr}_{\text {grass }}}{\mathrm{Ca}_{\text {grass }}}=f \frac{\mathrm{Sr}_{\text {soil }}}{\mathrm{Ca}_{\text {soil }}}$ 
where $\mathrm{Ca}$ and $\mathrm{Sr}$ refer to the bioavailable form of the element, and the factor $f$ accounts for a preferential uptake. $\mathrm{The} \mathrm{Sr} / \mathrm{Ca}$ ratios (or in analogy the $\mathrm{Cs} / \mathrm{K}$ ratios) of a soil can be viewed as a transfer potential. The higher $(\mathrm{Sr} / \mathrm{Ca})_{\text {soil }}$ is, the higher the corresponding $(\mathrm{Sr} / \mathrm{Ca})_{\text {vegetation }}$ should be. However, such a correlation is not apparent from the present data set.

\subsection{Milk and cheese contamination}

The results of milk and cheese activities in ${ }^{137} \mathrm{Cs}$ and ${ }^{90} \mathrm{Sr}$ are displayed in Table 5. Compared to soil and grass the activities of the radioisotopes are clearly less variable in the milk samples (for ${ }^{90} \mathrm{Sr}$ percentile 90 at 1.4 time the mean, Fig. 2). The cheese samples show a higher variability for ${ }^{90} \mathrm{Sr}$, which is due to several "outliers", i.e. cheese produced from winter-milk, where cows were fed differently (see below).

Strontium uptake by ruminants is influenced by the $\mathrm{Ca}$ uptake in a way that the $\mathrm{Sr} / \mathrm{Ca}$ ratio in the milk is proportional to the $\mathrm{Sr} / \mathrm{Ca}$ ratio in the intake (e.g. Beresford et al., 1998). Then the Sr content of milk is determined by its $\mathrm{Sr} /$ $\mathrm{Ca}$ ratio and the homeostatically controlled $\mathrm{Ca}$ requirement of $1.1 \mathrm{~g} \mathrm{Ca}^{-1}$. Geering et al. (1990) further showed that ${ }^{90} \mathrm{Sr}$ follows calcium from milk to cheese by the precipitation of the casein. We may assume that a similar dependence exists between Cs uptake and $\mathrm{K}$ uptake; the homeostatically controlled potassium content being $1.6 \mathrm{~g} \mathrm{~K}^{-1}$ (i.e. $50 \mathrm{~Bq} 1^{-140} \mathrm{~K}$ ) in cow milk. When passing from milk to cheese there is a ${ }^{137} \mathrm{Cs}$ decontamination, which is evidenced by the low ${ }^{137} \mathrm{Cs}$ activity in cheese compared to milk (Table 5). About 101 of milk are necessary to make $1 \mathrm{~kg}$ of cheese, which means that the decontamination factor of ${ }^{137} \mathrm{Cs}$ by cheese making is about 15 , based on the average values of Table 5. Froidevaux et al. (2004) found a decontamination factor of 20 for ${ }^{40} \mathrm{~K}$, an element analogous to caesium, by cheese making.

$\mathrm{Sr}$ is expected to be transferred to cheese together with $\mathrm{Ca}$ and the $\mathrm{Sr} / \mathrm{Ca}$ ratios (given in $\mathrm{Bq} \mathrm{g} \mathrm{Ca}{ }^{-1}$ ) are indeed very similar in milk and in cheese. However, four cheese samples show a tenfold decrease in ${ }^{90} \mathrm{Sr}$ activity compared to other dairy products in which ${ }^{90} \mathrm{Sr}$ activity is close to $0.5 \mathrm{~Bq} \mathrm{~g}^{-1} \mathrm{Ca}$ (Table 5). After an inquiry with the producer it became apparent that cow fodder can be supplied by maize and lowland forage during winter months. It is possible that the cheese samples collected in June came from a batch of winter cheese production, when the cows were not fed with the Mercantour grass. This situation does not show up in the milk samples that were taken by milking the cows directly on the field on which the herd was grazing. This findings highlight the potential of using ${ }^{90} \mathrm{Sr}$ activities in dairy products to trace their origin, especially for mountain cheeses, for which stringent production procedures are required in order to be awarded an 'appellation of origin'. In many cases, cheese production period is limited to the outdoor grazing period (Pillonel et al., 2003).
Any mixing of upland milk with lowland milk would be rather easily detected by a ${ }^{90} \mathrm{Sr}$ analysis.

\subsection{Relationship between the ${ }^{90} \mathrm{Sr}$ activity of dairy products and the altitude of grazing}

Due to the above discussed high variability of soil inventories measured on a single site (this study and cited references), a soil (or grass) sampling strategy does not seem ideal in environmental monitoring, especially when assessing large scale distribution patterns of radioactive fallout. We propose that contamination could be better estimated using diary product data, which represent homogenized values due to the vagrancy of the cows. Adapting Eq. (1) describing the soil-to-grass transfer, we may write the following equation for the soil-to-milk transfer:

$\frac{{ }^{90} \mathrm{Sr}_{\text {milk }}}{\mathrm{Ca}_{\text {milk }}}=f^{\prime} \frac{{ }^{90} \mathrm{Sr}_{\text {soil }}}{\mathrm{Ca}_{\text {soil }}}$

where $f^{\prime}$ summarizes the preferential transfer from soil to plant and from plant to milk (i.e. Beresford's, 1998, OM factor) and $\mathrm{Ca}$ refers to the bioavailable forms of the element. Admitting that global fallout in Western Europe depends on the altitude of a site (see Fig. 1) it follows from the above equation that ${ }^{90} \mathrm{Sr}$ in mountain dairy products should also depend on the altitude of grazing of the cows.

Fig. 3 is a diagram of ${ }^{90} \mathrm{Sr} / \mathrm{Ca}$ in dairy products as a function of altitude of grazing with the results obtained in this study as well as data from other published works (Geering et al., 1997; Gastberger et al., 2000; Froidevaux et al., 2004) or data from IRSN database. When the calcium content of milk was not known, a value of $1.1 \pm$ $0.1 \mathrm{~g} \mathrm{Ca}^{-1}$ of milk was used for calculation, based on an average value determined for 78 milk samples from Switzerland (Swiss Alps, Swiss lowland and Swiss Jura), between 1999 and 2003 (Froidevaux, unpublished results).

The altitude can be considered a proxy for total deposition but not for the $\mathrm{Sr} / \mathrm{Ca}$ ratio of the soil. By simply plotting $(\mathrm{Sr} / \mathrm{Ca})_{\text {milk }}$ versus altitude - instead of $(\mathrm{Sr} / \mathrm{Ca})_{\text {soil }}$ - we ignore the differences in bioavailable $\mathrm{Ca}_{\text {soil }}$, which,

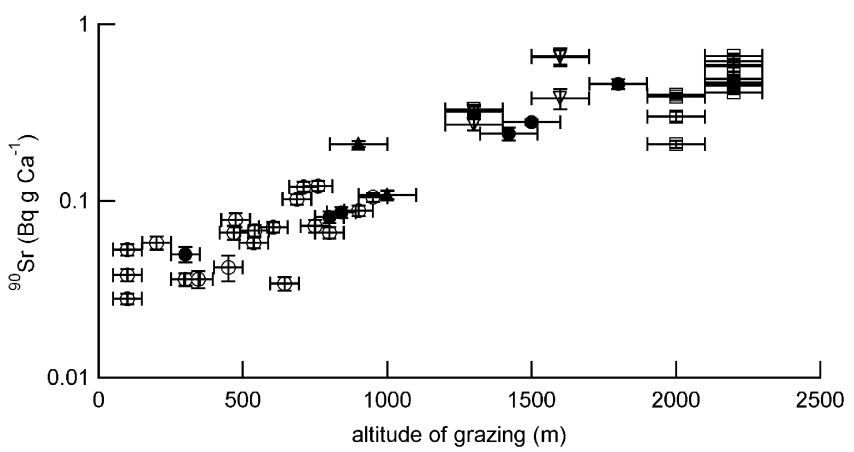

Fig. 3. ${ }^{90} \mathrm{Sr}$ activities in milk and cheese as a function of the altitude of grazing. Data from: this study (white square), Froidevaux et al., 2004 (white circle), Gastberger et al., 2000 (white triangle), Geering et al., 1997 (black circle) and IRSN database (black triangle). 
unfortunately, is not available for most of the studies. The fact that we still observe a good correlation may suggest that the variations of bioavailable $\mathrm{Ca}_{\text {soil }}$ are of minor importance. Another point to mention is that apart from deposition other factors may be responsible for the increase of Sr-inventories with altitude. There may be physical and chemical features of uplands soils that make ${ }^{90} \mathrm{Sr}$ and ${ }^{137} \mathrm{Cs}$ more abundant in the top layer of the soil (e.g. Gastberger et al., 2000) and contribute to the observed trend.

Even if it only approximately represents the above soilto-milk transfer model (Eq. (2)) the positive correlation between the altitude of grazing and ${ }^{90} \mathrm{Sr}$ activities is convincing and is confirmed by fitting the data to the following equation:

$A=A_{0}+\mathrm{e}^{k \cdot h}$

where $A_{0}$ is the expected activity of milk sampled at sea level and $h$ is the altitude of grazing, $k$ being a constant.

The parameters of best fit are $A_{0}=0.064 \pm 0.014 \mathrm{~Bq} \mathrm{~g}^{-1}$ $\mathrm{Ca}$ and $k=0.95 \times 10^{-3} \pm 0.11 \times 10^{-3} \mathrm{~m}^{-1} \mathrm{~Bq} \mathrm{~g}^{-1} \mathrm{Ca}$. The $A_{0}$ value is very close to the values determined for milk from cows grazing at sea level. For example, ${ }^{90} \mathrm{Sr}$ activity in milk is $0.045 \mathrm{~Bq} \mathrm{~g}^{-1} \mathrm{Ca}$ and $0.062 \mathrm{~Bq} \mathrm{~g}^{-1} \mathrm{Ca}$ in Blayais $(+5 \mathrm{~m}$ above sea level) and in Penly $(+15 \mathrm{~m})$, sites located at the edge of the Atlantic Ocean and the Channel respectively (IRSN database). In Brittany $(+100 \mathrm{~m})$ cheeses have an average ${ }^{90} \mathrm{Sr}$ value of $0.04 \pm 0.01 \mathrm{~Bq} \mathrm{~g}^{-1} \mathrm{Ca}$ (Froidevaux et al., 2004). This relationship (Eq. (3)) is valid only for Western Europe and for areas where ${ }^{90} \mathrm{Sr}$ deposited following the Chernobyl nuclear power plant accident can be considered as negligible.

This here-established relationship suggests that milk (and in the case of ${ }^{90} \mathrm{Sr}$ also cheese samples) are more robust indicators of large-scale contamination than soil or grass samples. Due to the high heterogeneity of the soil and grass contamination by ${ }^{90} \mathrm{Sr}$ and ${ }^{137} \mathrm{Cs}$, it is questionable whether these compartments are well suited for the environmental survey of uplands. In our opinion, milk - a readily available and easy to handle sample - is most useful to evaluate the extent of the environmental contamination by ${ }^{90} \mathrm{Sr}$ and ${ }^{137} \mathrm{Cs}$ fallout on a regional scale. Thus a sampling strategy aimed at evaluating the contamination of the environment should - if possible - focus on this particular sample.

\section{Conclusions}

The study of ${ }^{137} \mathrm{Cs},{ }^{90} \mathrm{Sr}$ and ${ }^{239+240} \mathrm{Pu}$ deposition in soil samples of a field site in the Western Alps (France) evidences large heterogeneity within a small area, confirming the difficulty to correctly estimate soil contamination of mountainous regions. This heterogeneity is still observed for ${ }^{137} \mathrm{Cs}$ and ${ }^{90} \mathrm{Sr}$ in grass. Although factors such as soil adherence to grass and competitive interaction between fission product and some major cations (e.g. $\mathrm{Ca}$ and $\mathrm{K}$ ) partly explain the variability of grass activities, it seems that the heterogeneity observed for this compartment mostly mirrors that of the soil. Results of ${ }^{137} \mathrm{Cs}$ and ${ }^{90} \mathrm{Sr}$ for dairy products show much more homogeneity, which is likely due to cow vagrancy over a larger area. Thus, milk samples seem to be more appropriate to assess radioisotope contamination of larger areas. This hypothesis was tested using a comprehensive set of ${ }^{90} \mathrm{Sr}$ soil and milk data from Western Europe. For this region the altitude is one of the most important primary parameters controlling the atmospheric deposition of radioisotopes. Therefore, ${ }^{90} \mathrm{Sr}$ activities were plotted against the altitude of sampling locations. A significant correlation was revealed between the soil ${ }^{90} \mathrm{Sr}$ inventories and altitude. An even better correlation was obtained between ${ }^{90} \mathrm{Sr}$ in dairy products against the altitude of grazing. This confirms that milk samples are very well suited for evaluation of the extent of a contamination by ${ }^{90} \mathrm{Sr}$ (and possibly by ${ }^{137} \mathrm{Cs}$ ) in radioactivity monitoring of mountainous area. Thus, we propose to evaluate the ${ }^{90} \mathrm{Sr}$ deposition over large areas by measuring radioactivity in milk samples only. For nuclear weapon test fallout, we evidenced that ${ }^{90} \mathrm{Sr}$ activity of milk can be used to evaluate ${ }^{90} \mathrm{Sr}$ surface deposition and a simple hypsometric model using the correlation of ${ }^{90} \mathrm{Sr}$ with altitude gave a very good estimate of total ${ }^{90} \mathrm{Sr}$ fallout in Switzerland.

\section{Acknowledgements}

Thank you to F. Barraud and T. Schmittler for their technical help. Thank you to J.-J. Geering for the determination of ${ }^{90} \mathrm{Sr}$ deposition in Switzerland. This work was supported by the Swiss Federal Office of Public Health under contract no. 3189.001.4. The authors also thank J. Marquet for excellent field assistance.

\section{References}

Albers, B.P., Rackwitz, R., Schimmack, W., Bunzl, K., 1998. Transect survey of radiocesium in soils and plants of two alpine pastures. Sci. Total Environ. 216, 159-172.

Albers, B.P., Steindl, H., Schimmack, W., Bunzl, K., 2000. Soil-to-plant and plant-to-cow's milk transfer of radiocaesium in alpine pastures: significance of seasonal variability. Chemosphere 41, 717-723.

Baeza, A., Paniagua, J.M., Rufo, M., Barandica, J., Sterling, A., 1999. Dynamic of ${ }^{90} \mathrm{Sr}$ and ${ }^{137} \mathrm{Cs}$ in a soil-plant system of a Mediterranean ecosystem. Radiochim. Acta 85, 137-141.

Beresford, N.A., Howard, B.J., 1991. The importance of soil adhered to vegetation as a source of radionuclides ingested by grazing animals. Sci. Total Environ. 107, 237-254.

Beresford, N.A., Mayes, R.W., Hansen, H.S., Crout, N.M.J., Hove, K., Howard, B.J., 1998. Generic relationship between calcium intake and radiostrontium transfer to the milk of dairy ruminants. Radiat. Environ. Bioph. 37, 129-131.

Beresford, N.A., Barnett, C.L., Coward, P.A., Howard, B.J., Mayes, R.W., 2002. A simple method for the estimation of the bioavailability of radiocaesium from herbage contaminated by adherent soil. $\mathrm{J}$ Environ. Radioactiv. 63, 77-84.

Bouisset, P., Calmet D., 1997. Status of measurement techniques for the identification of nuclear signatures. In: Proceeding of the International Workshop on the Status of Measurement Techniques for the Identification of Nuclear Signatures, Geel.

Bundt, M., Albrecht, A., Froidevaux, P., Blaser, P., Flühler, H., 2000. Impact of preferential flow on radionuclide distribution in soil. Environ. Sci. Technol. 34, 3895-3899. 
Bunzl, K., Albers, B.P., Schimmack, W., Belli, W., Ciuffo, L., Menegon, S., 2000. Soil-to-plant and plant-to-cow's milk transfer of radiocaesium in alpine pastures: Significance of seasonal variability. J. Environ. Radioactiv. 48, 145-158.

Currie, L.A., 1995. Nomenclature in evaluation of analytical methods including detection and quantification capabilities. Pure Appl. Chem. 67, 1699-1723.

Ehlken, S., Kirchner, G., 2002. Environmental processes affecting plant root uptake of radioactive trace elements and variability of transfer factor data: a review. J. Environ. Radioactiv. 58, 97-112.

Froidevaux, P., Geering, J.-J., Valley, J.-F., 2002. Strontium-90 determination in biological and environmental samples by direct milking of its daughter product, yttrium-90. J. Radioanal. Nucl. Chem. 254, 23-27.

Froidevaux, P., Geering, J.-J., Pillonel, L., Bosset, J.-O., Valley, J.-F., 2004. ${ }^{90} \mathrm{Sr},{ }^{238} \mathrm{U},{ }^{234} \mathrm{U},{ }^{137} \mathrm{Cs},{ }^{40} \mathrm{~K}$ and ${ }^{239 / 240} \mathrm{Pu}$ in Emmental type cheese produced in different regions of Western Europe. J. Environ. Radioactiv. 72, 287-298.

Gastberger, M., Steinhäusler, F., Gerzabek, M.H., Lettner, H., Hubmer, A., 2000. Soil-to-plant transfer of fallout caesium and strontium in Austrian lowland and alpine pastures. J. Environ. Radioactiv. 49, 217 233.

Geering, J.-J., Friedli, C., Lerch, P., 1990. Method of determination of ${ }^{90} \mathrm{Sr}$ in the environment. J Trace Microprobe T. 8, 211-230.

Geering, J.-J., Froidevaux, P., Valley, J.-F., Burger, M., Holzer, R., Figueiredo, V., Hermann, A., 1997. Environmental radioactivity and radiation exposure in Switzerland. Swiss Federal Office of Public Health, Fribourg, ISBN 3-905235-28-5.

Hölgye, Z., Filgas, R., 1995. Inventory of ${ }^{238} \mathrm{Pu}$ and ${ }^{239,240} \mathrm{Pu}$ in the soil of Czechoslovakia in 1990. J. Environ. Radioactiv. 27, 181-189.

Hölgye, Z., Schelsingerova, E., Tecl, J., Filgas, R., 2004. ${ }^{238} \mathrm{Pu},{ }^{239,240} \mathrm{Pu}$, ${ }^{241} \mathrm{Am},{ }^{90} \mathrm{Sr}$ and ${ }^{137} \mathrm{Cs}$ in soils around nuclear research centre Rez, near Prague. J. Environ. Radioactiv. 71, 115-125.

Jia, G., Testa, C., Desideri, D., Guerra, F., Meli, M., Roselli, C., Belli, M., 1999. Soil concentration, vertical distribution and inventory of plutonium, ${ }^{241} \mathrm{Am},{ }^{90} \mathrm{Sr}$ and ${ }^{137} \mathrm{Cs}$ in the Marche Region of Central Italy. Health Phys. 77, 52-61.

Lettner, H., Bossew, P., Hubmer, A.K., 1999. Spatial variability of fallout Caesium-137 in Austrian alpine regions. J. Environ. Radioactiv. 47, $71-82$.
Malek, M.A., Hinton, T.G., Webb, S.B., 2002. A comparison of ${ }^{90} \mathrm{Sr}$ and ${ }^{137}$ Cs uptake in plants via three pathways at two Chernobyl-contaminated sites. J. Environ. Radioactiv. 58, 129-141.

Mitchell, P.I., Sanchez-Cabeza, J.A., Ryan, T.P., McGarry, A.T., VidalQuatras, A., 1990. Preliminary estimates of cumulative caesium and plutonium deposition in the Irish terrestrial environment. J. Radioanal. Nucl. Chem. 138, 241-256.

Pillonel, L., Badertscher, R., Froidevaux, P., Haberhauer, G., Hölzl, S., Horn, P., Jakob, A., Pfammatter, E., Piantini, U., Rossmann, A., Tabacchi, R., Bosset, J.-O., 2003. Stable isotope ratios, major, trace and radioactive elements in emmental cheeses of different origins. Food Sci. Technol. - Leb. 36, 615-623.

Pourcelot, L., Renaud, P., Louvat, D., Gurriaran, R., Richon, P., 2003a. Influence des points de concentration en césium-137 sur la contamination d'une chaîne alimentaire de type alpin et doses associées. Environ. Risques et Santé. 2, 112-120.

Pourcelot, L., Louvat, D., Gauthier-Lafaye, F., Stille, P., 2003b. Formation of radioactivity enriched soils in mountain areas. J. Environ. Radioactiv. 68, 215.

Schimmack, W., Kracke, W., Sommer, M., 2003. Spatial variability of fallout ${ }^{90} \mathrm{Sr}$ in soil and vegetation of an alpine pasture. J. Environ. Radioactiv. 65, 281-296.

Touazi, M., Laborde, J.-P., Bhiry, N., 2004. Modeling rainfall-discharge at a mean inter-yearly scale in northern Algeria. J. Hydrol. 296, 179-191.

UNSCEAR, 1977. Sources and Effects of Ionising Radiation. United Nation publication, Vienna.

Ulsh, B., Rademacher, S., Ward Whicker, F., 2000. Variations of ${ }^{137} \mathrm{Cs}$ depositions and soil concentrations between alpine and montane soils in northern Colorado. J Environ Radioactiv. 47, 57-70.

Weingartner, R., Pearson, Ch. A., 2001. Comparison of the hydrology of the Swiss Alps and the Southern Alps of New Zealand. Mater. Res. Dev. 4, 370-381.

Wright, S.M., Howard, B.J., Strand, P., Nylen, T., Sickel, M.A.K., 1999. Prediction of ${ }^{137} \mathrm{Cs}$ deposition from atmospheric nuclear weapons tests within the Arctic. Environ. Pollut. 104, 131-143.

Yoshida, S., Muramatsu, Y., Dvornik, A.M., Zhuchenko, T.A., Linkov, I.J., 2004. Equilibrium of radiocesium with stable cesium within the biological cycle of contaminated forest ecosystems. J. Environ. Radioactiv. 75, 301-313. 